\title{
Customer Service Marketing Management of Power Supply Enterprise in Big Data Context
}

\author{
Lixian Xing \\ Department of Economics and Management \\ North China Electric Power University \\ Baoding, China \\ xlxwhy@sina.com
}

\author{
Liying Yang \\ Department of Economics and Management \\ North China Electric Power University \\ Baoding, China \\ yangly_94@126.com
}

\author{
Xue Zhao \\ Department of Economics and Management \\ North China Electric Power University \\ Baoding, China \\ vkvk_6344@163.com
}

\begin{abstract}
In the recent reform of electric power enterprises, big consumers' direct power purchase is the main factor in the decline of profits of electric power enterprises. Electric power enterprise needs to make out rational big consumers marketing strategies. The rational strategies could prevent the customer drains and corresponding negative influence to electric power enterprise efficiently. This paper used the ISM method to formula the influencing factors of big consumer management into hierarchical multiple model. To protect electric power enterprises from the profits decrease, it explores the deep factors in key account management and make out targeted marketing strategies.
\end{abstract}

Keywords-Electric power enterprise; ISM; Key account management; Marketing strategies

\section{INTRODUCTION}

In the modern society, electricity is the main driving factor to the economic growth. With the reformation of electric power system further intensified, the electric power enterprise, as the main supplier of electricity, is confronted with the fiercer market competition gradually [1]. Moreover, traditional business models could not solve the problems that the electric power enterprise is faced with. The electric power enterprise should define the current marketing condition in electricity market, and then increase competition via carrying out effective strategies. The development of technology contributes the advance in informatization degree of electric power enterprise. Then business data, marketing data, and financial data etc. could be recorded in enterprise information system and to be analyzed. The electric power enterprise might enhance quality and efficient of business marketing based on the results elicited with data analysis.

\section{THE ANALYSIS OF THE ELECTRIC POWER ENTERPRISE'S} ECONOMIC BENEFIT AND ITS INFLUENCING FACTORS

The data used in this paper are elected from China Electric Power Yearbook (2011-2015).

TABLE I. THE DATA OF ELECTRICITY SALES IN A ELECTRIC POWER ENTERPRISE DURING 2011-2015

\begin{tabular}{|c|c|c|c|c|}
\hline Year & $\begin{array}{c}\text { Main } \\
\text { business } \\
\text { income } \\
\text { [billion } \\
\text { yuan] }\end{array}$ & $\begin{array}{c}\text { Annual } \\
\text { growth rate } \\
{[\%]}\end{array}$ & $\begin{array}{c}\text { Electricity } \\
\text { sales } \\
\text { [billion kwh] }\end{array}$ & $\begin{array}{c}\text { Annual } \\
\text { growth rate } \\
\text { [\%] }\end{array}$ \\
\hline 2011 & 16754 & 8.601802035 & 30925 & 15.00130155 \\
\hline 2012 & 18830 & 12.39107079 & 32539 & 5.219078416 \\
\hline 2013 & 20498 & 8.858204992 & 35227 & 8.260856203 \\
\hline 2014 & 20914 & 2.029466289 & 34694 & -1.513043972 \\
\hline 2015 & 20750 & -0.784163718 & 34506 & -0.54188044 \\
\hline
\end{tabular}

Table 1 showed the detailed data of the main business income and electricity sales during 2011-2015. During 20122014 , the main business income in a electric power enterprise increases from 18830 to 20914 billion yuan, and the annual growth rates are decreasing from $12.39 \%$ to $2.02 \%$. Until 2015 , the main business income reduces by 164 billion, and the growth rate is $-0.78 \%$. The quantity of electricity sales of the current electricity market could reflect the power enterprise's benefit status, because electricity sales accounted for $93 \%$ of main income. In the recent years, the factors of reduction of profits in power enterprise might be follows: firstly, China's economic slowdown means total social electricity consumption decline; Secondly, to committee against environmental pollution, the quantity of small and unqualified industry enterprises was forced to shut down; Moreover, the policy of big consumers' direct power purchase leads to the changes of power enterprise's profit directly. 


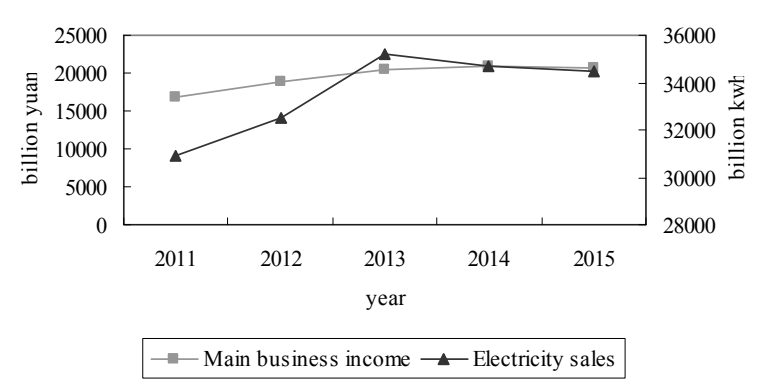

Fig. 1. The data of electricity sales in a electric power enterprise during 2011-2015

TABLE II. THE TOTAL ELECTRICITY CONSUMPTION [BILLION KWH]

\begin{tabular}{|c|c|c|c|c|c|c|}
\hline \multirow[b]{2}{*}{ year } & \multicolumn{4}{|c|}{ The industrial sector } & \multirow[b]{2}{*}{$\begin{array}{l}\text { The } \\
\text { residential } \\
\text { sector }\end{array}$} & \multirow[b]{2}{*}{ Total } \\
\hline & $\begin{array}{c}\text { The } \\
\text { primary } \\
\text { industry }\end{array}$ & $\begin{array}{c}\text { The } \\
\text { secondary } \\
\text { industry }\end{array}$ & $\begin{array}{c}\text { The } \\
\text { tertiary } \\
\text { industry }\end{array}$ & Total & & \\
\hline 2011 & 1014 & 35282 & 5105 & 41401 & 5621 & 47022 \\
\hline 2012 & 1004 & 36725 & 5694 & 43423 & 6235 & 49658 \\
\hline 2013 & 1026 & 39335 & 6269 & 46630 & 6793 & 53423 \\
\hline 2014 & 1013 & 41017 & 6670 & 48701 & 6936 & 55637 \\
\hline 2015 & 1020 & 40046 & 7158 & 48224 & 7276 & 55500 \\
\hline
\end{tabular}

Table 2 shows the social electricity consumption structure and the total social electricity consumption. We divided the total electricity consumption into the production sector and the household sectors to analyze. The electricity consumption proportion of various kinds of users could be obtained by data and statistics. The electricity consumption from the whole industrial sector accounted for $87 \%$ of the total. Thereinto, the electricity consumption of the secondary industry giving priority to the industry accounted for $84 \%$ of the industrial sector electricity usage. While, the big industrial user approximately accounted for $2 \%$ of the overall users. There would be a large losses accompanied by the left of a small number of industrial users.

The objective of big consumers' direct power purchase mainly is the big industrial users with high power consumption. Because of the limitation of transmission capacity principle and physical truth, electricity still is transferred to big users via the grid. This case changes the business pattern and the share of electric selling market. There is significance to study the marketing strategy related to big users for the electric power enterprise.

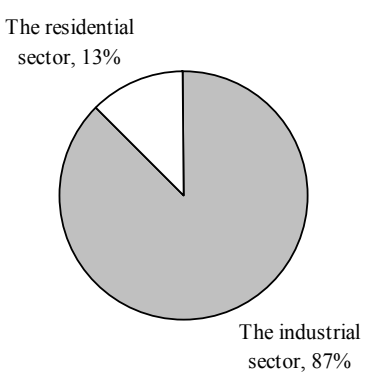

Fig. 2. The social electricity consumption structure

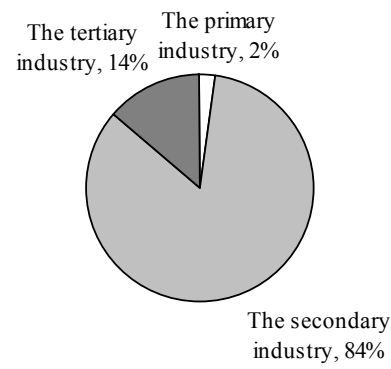

Fig. 3. The proportion of three times industry electricity consumption

\section{The Analysis of FaCtors to the Key ACCOUNT MANAGEMENT BASED ON ISM METHOD}

The efficient key account management is beneficial to improve the loyalty of big customer, then prevent losing clients. Finally, the electric power enterprise could improve electricity sales income. In this paper, we use ISM method to build multilevel hierarchical structure model to show the complex influential factor relationship, and to find the distal factors for maintain the loyalty of big customer. According to the distal factors, the enterprise could make out appropriate method of key account management and improvement marketing strategies.

Interpretative Structural Modeling (ISM) is a widely used analytical method in systems engineering [2]. This method could divide the complex system into many subsystems to build a multilevel hierarchical structure model. Based on the relative data analysis, we obtained the fifteen factors related to key account management $\left(\mathrm{S}_{1}\right)$ : Customer Satisfaction $\left(\mathrm{S}_{2}\right)$, Power Quality $\left(\mathrm{S}_{3}\right)$, Electricity Price $\left(\mathrm{S}_{4}\right)$, Customer Confidence $\left(\mathrm{S}_{5}\right)$, Power Supply Stability $\left(\mathrm{S}_{6}\right)$, Power Supply Security $\left(\mathrm{S}_{7}\right)$, Customer Communication $\left(\mathrm{S}_{8}\right)$, Service Channel $\left(\mathrm{S}_{9}\right)$, Service Level $\left(\mathrm{S}_{10}\right)$, Customer Care $\left(\mathrm{S}_{11}\right)$, Business Processing $\left(\mathrm{S}_{12}\right)$, Conversion Cost $\left(\mathrm{S}_{13}\right)$, Customer Property $\left(\mathrm{S}_{14}\right)$, Problem Processing $\left(\mathrm{S}_{15}\right)$. Then we built the adjacency matrix (A) to definite the logical relationship between all factors, and

$$
A_{\mathrm{m} \times n}=\left\{a_{i j}\right\}_{m \times n}
$$

The matrix element $\mathrm{a}_{i j}$ is defined as: 


$$
a_{i j}=\left\{\begin{array}{l}
1 \quad \text { there is relationsh ip between element } i \text { and } j \\
0 \quad \text { there is no relationsh ip between element } i \text { and } j
\end{array} i, j=1,2, \cdots \cdots, 15\right.
$$

The reachable matrix $(\mathrm{M})$ could be set up through Boole algebra method. When

$$
A_{\mathrm{r}-1}=(A+I)^{r-1}=R
$$

Matrix $\mathrm{R}$ is reachable matrix. There, the matrix $\mathrm{I}$ is unit matrix.

$$
\begin{aligned}
& \begin{array}{llllllllllllllllll}
S_{1} & S_{2} & S_{3} & S_{4} & S_{5} & S_{6} & S_{7} & S_{8} & S_{9} & S_{10} & S_{11} & S_{12} & S_{13} & S_{14} & S_{15}
\end{array} \\
& S_{1}\left[\begin{array}{lllllllllllllll}
0 & 0 & 0 & 0 & 0 & 0 & 0 & 0 & 0 & 0 & 0 & 0 & 0 & 0 & 0
\end{array}\right] \\
& S_{2} \quad \begin{array}{lllllllllllllll}
S_{3} & 0 & 0 & 0 & 0 & 0 & 0 & 0 & 0 & 0 & 0 & 0 & 0 & 0 & 0
\end{array} \\
& S_{3} \quad \begin{array}{llllllllllllllll} 
& 0 & 1 & 0 & 0 & 1 & 0 & 0 & 0 & 0 & 0 & 0 & 0 & 0 & 0 & 0
\end{array} \\
& S_{4} \quad \begin{array}{lllllllllllllll} 
& 1 & 0 & 0 & 0 & 0 & 0 & 0 & 0 & 0 & 0 & 0 & 0 & 0 & 0
\end{array}
\end{aligned}
$$

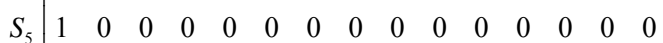

$$
\begin{aligned}
& S_{6} \mid \begin{array}{lllllllllllllll} 
& 0 & 1 & 0 & 0 & 0 & 0 & 0 & 0 & 0 & 0 & 0 & 0 & 0 & 0
\end{array} \\
& S_{7} \quad 0 \begin{array}{lllllllllllllll} 
& 0 & 1 & 0 & 0 & 0 & 0 & 0 & 0 & 0 & 0 & 0 & 0 & 0 & 0
\end{array} \\
& A=S_{8} \quad 0 \begin{array}{lllllllllllllll} 
& 1 & 0 & 0 & 0 & 0 & 0 & 0 & 0 & 0 & 1 & 0 & 0 & 0 & 0
\end{array} \\
& S_{9} \quad \begin{array}{llllllllllllllll}
0 & 0 & 0 & 0 & 0 & 0 & 0 & 0 & 0 & 1 & 0 & 0 & 0 & 0 & 0
\end{array} \\
& S_{10} \mid \begin{array}{lllllllllllllll}
0 & 1 & 0 & 0 & 1 & 0 & 0 & 0 & 0 & 0 & 0 & 0 & 0 & 0 & 0
\end{array}
\end{aligned}
$$

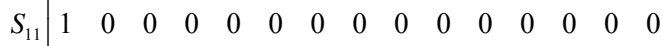

$$
\begin{aligned}
& S_{12} \quad \begin{array}{llllllllllllllll} 
& 0 & 0 & 0 & 0 & 0 & 0 & 0 & 0 & 1 & 0 & 0 & 0 & 0 & 0
\end{array} \\
& S_{13} 1 \begin{array}{lllllllllllllll}
1 & 0 & 0 & 0 & 0 & 0 & 0 & 0 & 0 & 0 & 0 & 0 & 0 & 0 & 0
\end{array} \\
& S_{14}\left[\begin{array}{lllllllllllllll}
0 & 0 & 0 & 0 & 0 & 0 & 0 & 0 & 0 & 0 & 1 & 0 & 1 & 0 & 0
\end{array}\right. \\
& S_{15}\left[\begin{array}{lllllllllllllll}
0 & 0 & 0 & 0 & 0 & 0 & 0 & 0 & 0 & 1 & 0 & 0 & 0 & 0 & 0
\end{array}\right.
\end{aligned}
$$

The reachable matrix is defined as $\mathrm{M}$.

\begin{tabular}{|c|c|c|c|c|c|c|c|c|c|c|c|c|c|c|c|}
\hline & & $\begin{array}{l}\mathrm{S}_{2} \\
0\end{array}$ & & 0 & 0 & 0 & 0 & 0 & $\begin{array}{l}J_{10} \\
0\end{array}$ & 0 & $\begin{array}{l}4^{4} 6 \\
\mid 0\end{array}$ & & 0 & 0 & 0 \\
\hline$S_{2}$ & 1 & 1 & 0 & 0 & 0 & 0 & 0 & 0 & 0 & 0 & 0 & 0 & 0 & 0 & 0 \\
\hline$S_{5}$ & 1 & 0 & 1 & 0 & 0 & 0 & 0 & 0 & 0 & 0 & 0 & 0 & 0 & 0 & 0 \\
\hline$S_{11}$ & 1 & 0 & 0 & 1 & 0 & 0 & 0 & 0 & 0 & 0 & 0 & 0 & 0 & 0 & 0 \\
\hline$S_{13}$ & 1 & 0 & 0 & 0 & 1 & 0 & 0 & 0 & 0 & 0 & 0 & 0 & 0 & 0 & 0 \\
\hline$S_{4}$ & 1 & 1 & 0 & 0 & 0 & 1 & 0 & 0 & 0 & 0 & 0 & 0 & 0 & 0 & 0 \\
\hline$S_{3}$ & 1 & 1 & 1 & 0 & 0 & 0 & 1 & 0 & 0 & 0 & 0 & 0 & 0 & 0 & 0 \\
\hline$'=S_{8}$ & 1 & 1 & 0 & 1 & 0 & 0 & 0 & 1 & 0 & 0 & 0 & 0 & 0 & 0 & 0 \\
\hline$S_{10}$ & 1 & 1 & 1 & 0 & 0 & 0 & 0 & 0 & 1 & 0 & 0 & 0 & 0 & 0 & 0 \\
\hline$S_{14}$ & 1 & 0 & 0 & 1 & 1 & 0 & 0 & 0 & 0 & 1 & 0 & 0 & 0 & 0 & 0 \\
\hline$S_{6}$ & 1 & 1 & 1 & 0 & 0 & 0 & 1 & 0 & 0 & 0 & 1 & 0 & 0 & 0 & 0 \\
\hline$S_{7}$ & 1 & 1 & 1 & 0 & 0 & 0 & 1 & 0 & 0 & 0 & 0 & 1 & 0 & 0 & 0 \\
\hline$S_{9}$ & 1 & 1 & 1 & 0 & 0 & 0 & 0 & 0 & 1 & 0 & 0 & 0 & 1 & 0 & 0 \\
\hline$S_{12}$ & 1 & 1 & 1 & 0 & 0 & 0 & 0 & 0 & 1 & 0 & 0 & 0 & 0 & 1 & 0 \\
\hline$S_{15}$ & {$[1$} & 1 & 1 & 0 & 0 & 0 & 0 & 0 & 1 & 0 & 0 & 0 & 0 & 0 & 1 \\
\hline
\end{tabular}

$$
\begin{aligned}
& \begin{array}{llllllllllllllllllll}
S_{1} & S_{2} & S_{3} & S_{4} & S_{5} & S_{6} & S_{7} & S_{8} & S_{9} & S_{10} & S_{11} & S_{12} & S_{13} & S_{14} & S_{15}
\end{array} \\
& S_{1}\left[\begin{array}{lllllllllllllll}
1 & 0 & 0 & 0 & 0 & 0 & 0 & 0 & 0 & 0 & 0 & 0 & 0 & 0 & 0
\end{array}\right]
\end{aligned}
$$

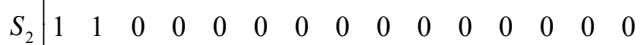

$$
\begin{aligned}
& S_{3} 1 \begin{array}{lllllllllllllll} 
& 1 & 1 & 0 & 1 & 0 & 0 & 0 & 0 & 0 & 0 & 0 & 0 & 0 & 0
\end{array}
\end{aligned}
$$

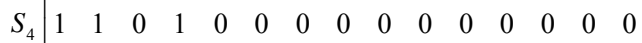

$$
\begin{aligned}
& S_{5} 1 \begin{array}{lllllllllllllll} 
& 0 & 0 & 0 & 1 & 0 & 0 & 0 & 0 & 0 & 0 & 0 & 0 & 0 & 0
\end{array} \\
& S_{6} \begin{array}{llllllllllllllll} 
& 1 & 1 & 0 & 1 & 1 & 0 & 0 & 0 & 0 & 0 & 0 & 0 & 0 & 0
\end{array} \\
& S_{7} 1 \begin{array}{lllllllllllllll} 
& 1 & 1 & 0 & 1 & 0 & 1 & 0 & 0 & 0 & 0 & 0 & 0 & 0 & 0
\end{array} \\
& M=S_{8} \begin{array}{llllllllllllllll}
1 & 1 & 0 & 0 & 0 & 0 & 0 & 1 & 0 & 0 & 1 & 0 & 0 & 0 & 0
\end{array} \\
& S_{9} 1 \begin{array}{lllllllllllllll} 
& 1 & 0 & 0 & 1 & 0 & 0 & 0 & 1 & 1 & 0 & 0 & 0 & 0 & 0
\end{array} \\
& S_{10} \mid \begin{array}{lllllllllllllll} 
& 1 & 0 & 0 & 1 & 0 & 0 & 0 & 0 & 1 & 0 & 0 & 0 & 0 & 0
\end{array}
\end{aligned}
$$

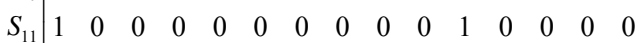

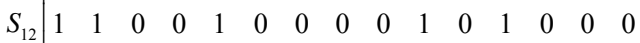

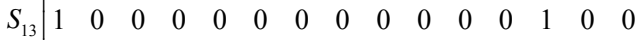

$$
\begin{aligned}
& S_{14} \mid \begin{array}{lllllllllllllll}
1 & 0 & 0 & 0 & 0 & 0 & 0 & 0 & 0 & 0 & 1 & 0 & 1 & 1 & 0
\end{array} \\
& S_{15}\left[\begin{array}{lllllllllllllll}
1 & 1 & 0 & 0 & 1 & 0 & 0 & 0 & 0 & 1 & 0 & 0 & 0 & 0 & 1
\end{array}\right]
\end{aligned}
$$

Then, eliminated the strong connection between the elements in matrix $\mathrm{M}$ to reduce the matrix scale.

By hierarchical matrix processing, the new matrix $\mathrm{M}^{\prime}$ would be elicited.
Then, extracted the skeleton matrix $\mathrm{A}^{\prime}$.

$$
\begin{aligned}
& \begin{array}{lllllllllllllllll}
S_{1} & S_{2} & S_{5} & S_{11} & S_{13} & S_{4} & S_{3} & S_{8} & S_{10} & S_{14} & S_{6} & S_{7} & S_{9} & S_{12} & S_{15}
\end{array} \\
& S_{1}\left[\begin{array}{lllllllllllllll}
0 & 0 & 0 & 0 & 0 & 0 & 0 & 0 & 0 & 0 & 0 & 0 & 0 & 0 & 0
\end{array}\right]
\end{aligned}
$$

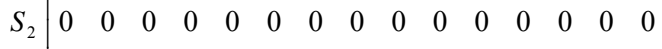

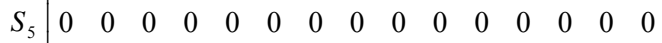

$$
\begin{aligned}
& S_{11} \mid \begin{array}{lllllllllllllll} 
& 0 & 0 & 0 & 0 & 0 & 0 & 0 & 0 & 0 & 0 & 0 & 0 & 0 & 0
\end{array} \\
& S_{13} \mid \begin{array}{lllllllllllllll} 
& 0 & 0 & 0 & 0 & 0 & 0 & 0 & 0 & 0 & 0 & 0 & 0 & 0 & 0
\end{array}
\end{aligned}
$$

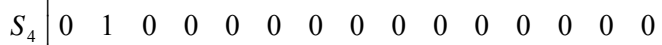

$$
\begin{aligned}
& S_{3} \quad 0 \begin{array}{lllllllllllllll} 
& 1 & 1 & 0 & 0 & 0 & 0 & 0 & 0 & 0 & 0 & 0 & 0 & 0 & 0
\end{array}
\end{aligned}
$$

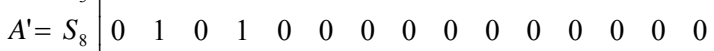

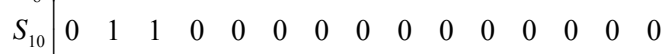

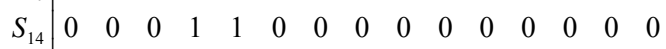

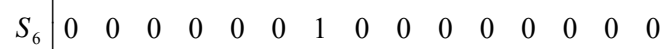

$$
\begin{aligned}
& S_{7}\left[\begin{array}{lllllllllllllll} 
& 0 & 0 & 0 & 0 & 0 & 1 & 0 & 0 & 0 & 0 & 0 & 0 & 0 & 0
\end{array}\right.
\end{aligned}
$$

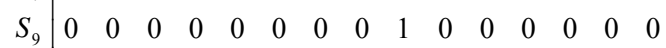

$$
\begin{aligned}
& S_{12}\left[\begin{array}{lllllllllllllll} 
& 0 & 0 & 0 & 0 & 0 & 0 & 0 & 1 & 0 & 0 & 0 & 0 & 0 & 0
\end{array}\right. \\
& S_{15}\left[\begin{array}{lllllllllllllll}
0 & 0 & 0 & 0 & 0 & 0 & 0 & 0 & 1 & 0 & 0 & 0 & 0 & 0 & 0
\end{array}\right]
\end{aligned}
$$

The final interpretation hierarchical structure mode could set up according to skeleton matrix A'. 


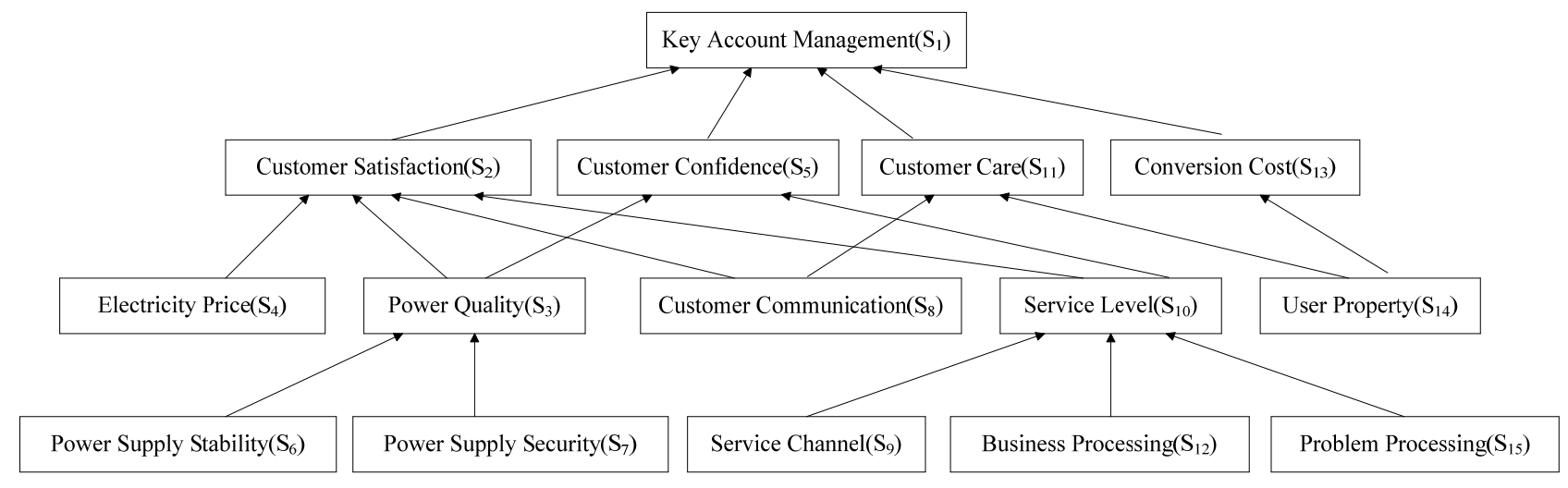

Fig. 4. The interpretation hierarchical of the key account management

The last hierarchical structure model showed that: Customer Satisfaction, Customer Confidence, Customer Care, and Conversion Cost were superficial factors; Power Quality, Electricity Price, Customer Communication, Service Level, User Property, and the factors below those were deep factors; Power Quality was influenced by Power Supply Stability and Power Supply Security. Service Channel, Business Processing, and Problem Processing affected the Service Level. The electricity power enterprise should aim at the deep factors to make marketing strategy, and mainly manage the fields of the distal factors.

\section{Marketing Strategies to Key Account}

Big consumers could receive power through dedicated lines or power grid. The former needs big consumers or cooperative enterprises construct supply lines. Relative problems, such as repairs on power lines, need to be settled through negotiation. This pattern's operation is along with high cost, advanced techniques, and it would destroy the power grid planning and power lines' rebuilt. The latter transmits power via power grid, which is the development direction of big consumer's direct power purchase. The electricity power enterprise could rent power lines to obtain service payoff. Confronted with the open competition in electricity sales, power enterprises might establish or improve the marketing strategy from the following aspects.

\section{A. Improve power quality}

Power generation enterprises can make a big users face the risk of power supply because of the shortage of fuel or unscheduled shutdown. Relatively, the power supply stability and power supply security of the power grid enterprises are guaranteed, which could keep its advantage of the power supply.

There is necessary to optimize the grid architecture, longterm network construction planning, and improve its reliability [3]. Introducing advanced technology and processes, improving the level of equipment operation, and circumventing the risk of transmission congestion might ensure smooth lines; Regular visits to pose a safety hazard or overload of lines and equipment is also the appropriate action to avoid the accident. Regular maintenance lines and equipment, ensuring the security of the power supply. And power enterprise can install smart meters and other measuring devices for big consumers, which is contribute to receive remote monitoring information timely. Timely data collection and management is the driving factor to quickly determine the fault point, and to timely make emergency repair, real-time tracking, and improve the timeliness to restore power.

\section{B. Adopt floating electricity price}

Under the reasonable electricity price system, electricity price should be more flexible. A time-sharing electricity prices would encourage big customers arrange reasonable production activities and contribute to peak cut and reduce customers' electricity cost. Power enterprise should select discount prices. For large users signing long-term cooperation contract, discount electricity price could avoid by customer churn because of the great influence of electricity price fluctuation. Power enterprise also need take the wholesale electricity price, and establish the marketing pattern that the more electricity consumption, the lower the price. Implementation of electricity price in advance is an efficient way. If the clients pay the electricity bills in advance, the clients would enjoy the corresponding preferential policy. Promotion of linkage electricity price contributes to split profit between power supply enterprises and the big user.

\section{Improve service level}

The big customer satisfaction of enterprise's service level is to determine the main factors of customer loyalty. Power supply enterprises should focus of work to making service to meet the big customers demand. It is necessary to create the high-quality service brand, improve staff quality, and perfect the service system. For various customers, to provide diversified services and expand service channel, such as establishing a fully functional online business hall, or mobile business hall, would provide convenient services on business processing and information query. To shorten waiting time of business processing, there is necessary to open up big customer service zone and telephone lines to prioritize their business. Big customers are distinct with general customers, and to provide value-added services for big customers is attractive policy to big customers. For example, for large customers, the problems of electrical safety, saving energy, reducing consumption, and the increase of efficiency of the power need the more targeted services [4,5]. 


\section{Communicate with big customers timely}

Power supply enterprise should initiatively communicate with the big customers, and establish effective communication mechanism [6]. For example, enterprise sends stuff regularly to visit big customers. Listen to customers' comments and suggestions widely. Then perfect products and services according to the suggestion. Communication is also the way to find the potential needs of customers to collect and update the important information in time. It is significant to take care of customer relationship management (CRM).

\section{E. Identify the customer property}

Power supply enterprises should identify customer industry and the electricity using characteristics of that very industry. Based on the industrial development trend, power supply enterprise need to estimate the customer property and explore the nature of customer from the multiple levels. By supporting big customers' development, power supply enterprise can achieve mutual benefit and win-win results.

\section{CONCLUSION}

During the innovation of power market, big customers' direct power purchase directly led to declining profit of the power supply enterprise. This paper analyzes the large customer management based on ISM method quantitatively. And we suggest that power supply enterprises could prevent loss of big customers and ensure that the power supply corporate earnings from five aspects. Firstly, power supply enterprise should adjust electricity price reasonably. Secondly, it is necessary to ensure the power supply reliability and voltage stability for improving the power quality. Then, perfective service channel is attractive to big customers. To improve the efficiency of deal with business issues is important in key account management. And regular and efficient communication also contributes to resolve the problem timely. According to the different properties of the customers, to make personalized business planning is helpful to ensure the loyalty of big customers.

\section{REFERENCES}

[1] H. B. Jiao, "The analysis and planning of big user's direct power purchase in electricity market," New Technology \& New Products of China, vol 05, 2015, pp. 58. (In Chinese)

[2] M. J. Xu, "Analysis of the factors of electricity demand based on the interpretive structure model," Electric Power, vol. 04, 2009, pp. 1-5. (In Chinese)

[3] A. F. Luo, "Study on the strategies of the key account management in power supply enterprise," Technology and Market, vol 12, 2014, pp. 246-247. (In Chinese)

[4] M. N. Zhang, K. Z. Rao, "The exploration of improvement of Electricity check and Customer service levels for big user," New Technology \& New Products of China, vol 07, 2016, pp. 166-167. (In Chinese)

[5] Y. H. Zeng, "How to improve the quality of marketing services of power supply enterprise, Telecom World," vol 01, 2015, pp. 179-180. (In Chinese)

[6] H. B. Jiao, J. H. Cui, "Study on the key account marketing strategies of power supply enterprise," Science \& Technology Information, vol 12, 2015, pp. 153. (In Chinese) 